\title{
Diagnosis of posterior cutaneous nerve entrapment syndrome through history and physical examination
}

\author{
Takashi Watari, ${ }^{1,2}$ Nami Yoshimura, ${ }^{3}$ Ashwin Gupta ${ }^{4,5}$
}

${ }^{1}$ General Medicine Center,

Shimane University Hospital, Izumo, Shimane, Japan

${ }^{2}$ Division of Hospital Medicine, University of Michigan Medical School, Ann Arbor, Michigan, USA

${ }^{3}$ Department of General Medicine, Shimane Prefectural Central Hospital, Izumo, Shimane, Japan

${ }^{4}$ Department of Medicine, University of Michigan Medical School, Ann Arbor, Michigan, USA

${ }^{5}$ Medicine Service, VA Ann Arbor Healthcare System, Ann Arbor, Michigan, USA

\section{Correspondence to}

Dr Takashi Watari:

wataritari@gmail.com

Accepted 7 February 2022
Check for updates

(C) BMJ Publishing Group Limited 2022. No commercial re-use. See rights and permissions. Published by BMJ.

To cite: Watari T,
Yoshimura N, Gupta A. BMJ
Case Rep 2022;15:e248661.
doi:10.1136/bcr-2021-
248661

\section{DESCRIPTION}

Posterior cutaneous nerve entrapment syndrome (POCNES) has recently been proposed as a cause of back pain that can neither be diagnosed through imaging nor blood tests. ${ }^{12}$ POCNES appears to be an intercostal nerve root disorder related to anterior CNES (ACNES) and lateral CNES (LACNES). ${ }^{1-4}$ There is both a limited awareness of and a lack of gold standard for diagnosing POCNES; hence, we present a case video demonstrating how to diagnose this disorder.

A woman in her 40s was referred from orthopaedic surgery to general medicine clinic for evaluation of severe left back pain of unspecified aetiology. Her pain began 12 days prior to her visit as a sharp pain in her left back and left chest, for which she had previously undergone unremarkable X-ray and ultrasound imaging. Based on the nature of the pain, she was treated with NSAIDs for suspected rib fracture. Four days prior to general medicine presentation, the patient noted worsening pain with physical activity and inability to turn over in bed. On visual examination of the back, no abnormalities were identified; however, the patient reported severe tenderness $(2 \mathrm{~cm} \times 2 \mathrm{~cm})$ to palpation left of thoracic vertebra 11 (Th11). The patient reported strong localised hypersensitivity to light touch, severe pain on light pinching (ie, positive pinch sign) ${ }^{3}$ and decreased cold sensitivity (figure 1). At rest, the patient's pain was persistent and numb (numerical rating scale, NRS $=5 / 10)$. With rotation and flexionextension of the trunk, the patient experienced intense, electric pain (NRS $=9 / 10)$. Consistent with the treatment of ACNES and LACNES, a local injection of $5 \mathrm{~mL}$ of $1 \%$ xylocaine was

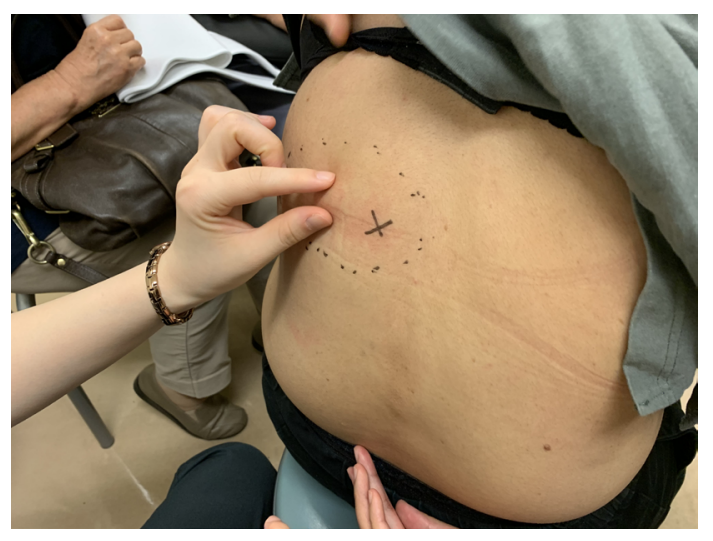

Figure 1 Tenderness and hyperalgesia at the level of Th11 while being examined by the pinch sign.

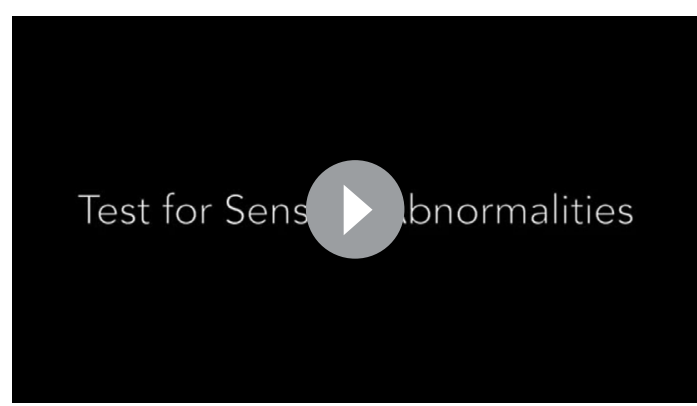

Video 1 Presentation and diagnosis of POCNES.

administered at the site of the pain. Ten minutes after the injection, her back pain and hypersensitivity resolved entirely; therefore, a superficial entrapment was deemed highly likely. She was thus diagnosed with POCNES (video 1). After the initial treatment, she had return of mild (NRS 2-3/10) but persistent pain, and after 2 months of visits to pain clinic her POCNES resolved without surgical intervention.

Pathologically, POCNES involved compression, entrapment or physical disturbance of the posterior cutaneous branches of the intercostal nerves, resulting in a characteristic pain. Diagnosis of POCNES is made through careful history taking and elicitation of the characteristic pain on physical examination. Laboratory testing and imaging are typically unhelpful in the diagnosis of POCNES, though may be useful in excluding alternative and potentially more concerning aetiologies of a patients presenting complaint. A differential diagnosis to be considered in a patient presenting with possible POCNES is presented in box 1 .

A previous study of POCNES $(n=14)$ indicated that thoracic vertebral levels 8-10 are most commonly affected. The time to diagnosis (TTD, mean 22 months, range 5-48 months) is relatively long because proper diagnosis depends on the physician's knowledge and experience with POCNES. ${ }^{25}$ This patient's presentation is generally consistent with prior studies, though with shorter TTD owing to physician familiarity with the diagnosis.

We believe diagnosis of POCNES requires three things. First, the pain should be consistent with neuropathic pain (eg, shooting, burning, tingling, numbness) and must be differentiated from rib fracture and other musculoskeletal back pain. Second, proper physical examination is crucial and should reveal a highly reproducible and localised tender point. The accuracy 


\section{Box 1 Differential diagnosis of POCNES}

\section{POCNES-like pain}

- Thoracic wall abnormality (haematoma, endometriosis, tumour and tear)

- Radiculopathy (traumatic, diabetic)

- Slipping rib syndrome

- Scar tissue

- Myofascial pain syndrome

- Rib abnormalities

- Postherpetic neuralgia

- Neurofibroma/Schwannoma

- Herniated disc

- Epidemic pleurodynia (Bornholm disease)

\section{Patient's perspective}

It would be nice if more medical professionals would recognise the disease I have been experiencing. I hope that this case will contribute to patients worldwide who are suffering in the same way. of the diagnosis is greatly improved by lightly pinching the skin in that area and searching for skin somatosensory abnormalities with swabs or ice. Third, trigger injections are highly effective. Almost all patients showed a reduction in pain at the first treatment (as seen in ACNES/LACNES). ${ }^{25}$ In the case of back pain of unclear aetiology, keeping in mind these diagnostic pearls may lead to an accurate and timely diagnosis of POCNES.

Acknowledgements We thank the team members, Dr Yoshihiko Shiraishi, Dr Ichiro Kato, Dr Seiji Odagawa, Dr Takeshi Endo, Dr Nobuyuki Ueno, Mrs Kazumi Iwatani, from Shimane University Hospital, General Medicine Center, for sharing their wisdom with us during this research. In addition, we also thank Dr Sanjay Saint for his remarkable diagnostic guidance and Mr Jason Engle for his English advice.

Contributors TW and NY cared for the patient. TW supervised NY for her physical examination. TW wrote the draft. AG revised the draft.

Funding The authors have not declared a specific grant for this research from any funding agency in the public, commercial or not-for-profit sectors.

Competing interests None declared.

Patient consent for publication Consent obtained directly from patient(s).

Provenance and peer review Not commissioned; externally peer reviewed.

Case reports provide a valuable learning resource for the scientific community and can indicate areas of interest for future research. They should not be used in isolation to guide treatment choices or public health policy.

\section{REFERENCES}

1 Breivik $H$, Stubhaug A. A new treatable chronic pain diagnosis? flank pain caused by entrapment of posterior cutaneous branch of intercostal nerves, lateral acnes coined LACNES. Scand J Pain 2017;17:201-2.

2 Boelens OB, Maatman RC, Scheltinga MR, et al. Chronic localized back pain due to posterior cutaneous nerve entrapment syndrome (POCNES): a new diagnosis. Pain Physician 2017;20:E455-8.

3 Watari T. Pinch sign for acute lateral cutaneous nerve entrapment syndrome (LACNES). BMJ Case Rep 2021;14:e241421.

4 Watari T, Tokuda Y. Anterior cutaneous nerve entrapment syndrome. BMJ Case Rep 2019;12:e232765.

5 Maatman RC, Boelens OB, Scheltinga MRM, et al. Chronic localized back pain due to entrapment of cutaneous branches of posterior rami of the thoracic nerves (POCNES): a case series on diagnosis and management. J Pain Res 2019;12:715-23.

Copyright 2022 BMJ Publishing Group. All rights reserved. For permission to reuse any of this content visit https://www.bmj.com/company/products-services/rights-and-licensing/permissions/

BMJ Case Report Fellows may re-use this article for personal use and teaching without any further permission.

Become a Fellow of BMJ Case Reports today and you can:

- Submit as many cases as you like

- Enjoy fast sympathetic peer review and rapid publication of accepted articles

- Access all the published articles

- Re-use any of the published material for personal use and teaching without further permission

Customer Service

If you have any further queries about your subscription, please contact our customer services team on +44 (0) 2071111105 or via email at support@bmj.com.

Visit casereports.bmj.com for more articles like this and to become a Fellow 